The Journal of Experimental Biology 216, 3148-3155 (C) 2013. Published by The Company of Biologists Ltd doi:10.1242/jeb.083550

RESEARCH ARTICLE

\title{
Aluminum exposure impacts brain plasticity and behavior in Atlantic salmon (Salmo salar)
}

\author{
C. Grassie ${ }^{1, *}$, V. A. Braithwaite ${ }^{1}$, J. Nilsson ${ }^{2}$, T. O. Nilsen ${ }^{3,4}$, H.-C. Teien ${ }^{5}$, S. O. Handeland ${ }^{3}$, \\ S. O. Stefansson ${ }^{4}$, V. Tronci ${ }^{3}$, M. Gorissen ${ }^{6}$, G. Flik ${ }^{6}$ and L. O. E. Ebbesson ${ }^{3}$ \\ ${ }^{1}$ Department of Ecosystem Science and Management, Pennsylvania State University, University Park, PA 16802, USA, ${ }^{2}$ Institute of \\ Marine Research, PO Box 1870 Nordnes, N-5817 Bergen, Norway, ${ }^{3}$ Uni Research AS, N-5006 Bergen, Norway, ${ }^{4}$ Department of \\ Biology, University of Bergen, PO Box 7800, N-5020 Bergen, Norway, ${ }^{5}$ Norwegian University of Life Science, Department of Plant \\ and Environmental Sciences, Box 5003, 1432 Ås, Norway and ${ }^{6}$ Department of Animal Physiology, Institute for Water and Wetland \\ Research, Radboud University Nijmegen, Heyendaalseweg 135, 6525 AJ Nijmegen, The Netherlands \\ *Author for correspondence (ocg102@psu.edu)
}

\begin{abstract}
SUMMARY
Aluminum (AI) toxicity occurs frequently in natural aquatic ecosystems as a result of acid deposition and natural weathering processes. Detrimental effects of Al toxicity on aquatic organisms are well known and can have consequences for survival. Fish exposed to $\mathrm{Al}$ in low $\mathrm{pH}$ waters will experience physiological and neuroendocrine changes that disrupt homeostasis and alter behavior. To investigate the effects of Al exposure on both the brain and behavior, Atlantic salmon (Salmo salar) kept in water treated with $\mathrm{Al}\left(\mathrm{pH} 5.7,0.37 \pm 0.04 \mu \mathrm{mol}^{-1} \mathrm{Al}\right)$ for 2 weeks were compared with fish kept in under control conditions ( $\mathrm{pH} 6.7$, $<0.04 \mu \mathrm{mol}^{-1} \mathrm{Al}$ ). Fish exposed to $\mathrm{Al}$ and acidic conditions had increased $\mathrm{Al}$ accumulation in the gills and decreased gill $\mathrm{Na}^{+}$, $\mathrm{K}^{+}-$ ATPase activity, which impaired osmoregulatory capacity and caused physiological stress, indicated by elevated plasma cortisol and glucose levels. Here we show for the first time that exposure to Al in acidic conditions also impaired learning performance in a maze task. Al toxicity also reduced the expression of NeuroD1 transcript levels in the forebrain of exposed fish. As in mammals, these data show that exposure to chronic stress, such as acidified Al, can reduce neural plasticity during behavioral challenges in salmon, and may impair the ability to cope with new environments.
\end{abstract}

Key words: parr-smolt transformation, telencephalon, salmonid, spatial learning, chronic mild stress, physiology.

Received 1 December 2012; Accepted 24 April 2013

\section{INTRODUCTION}

Acid deposition causes acidification of many aquatic habitats worldwide; furthermore, it can cause aluminum (Al) toxicity through mobilization of Al from surrounding soil into adjacent waterways (Schindler, 1988). In water, Al can be present in different physicochemical forms, but it is well established that $\mathrm{Al}$ cations are the bioavailable and toxic forms of $\mathrm{Al}$, and that $\mathrm{Al}$ associated with organic material such as humic substances are less toxic (Gensemer and Playle, 1999; Teien et al., 2006). Many aquatic organisms are sensitive to such changes in water quality, and the detrimental effects of $\mathrm{Al}$ in acidified water have been studied in plants (Lovett et al., 2009), invertebrates (Guerold et al., 2000), amphibians (Brady and Griffiths, 1995) and fish (Kroglund et al., 2008; Poléo et al., 1997). Thus Al toxicity has significant, negative implications for the biodiversity and functioning of many ecosystems (Horne and Dunson, 1995; Lovett et al., 2009). To effectively manage aquatic habitats threatened by acid precipitation and the resulting $\mathrm{Al}$ pollution, it is necessary to identify and understand how different species are affected (Dudgeon et al., 2006).

Teleostean fishes, similar to other vertebrates, react to changes in the environment through the stress response - a series of behavioral and physiological adjustments mediated by a number of neuroendocrine pathways (Barton, 2002). In fish, the combined effects of acidified water and Al toxicity produce physiological changes such as disruption of gas and ion transport, altered blood chemistry and hormonal imbalance (Camargo et al., 2009; Neff et al., 2009; Nilsen et al., 2010). Such physiological changes can disrupt behaviors such as foraging and competition (Øverli et al., 2006; Sørensen et al., 2007), and can have consequences for growth and survival (Biro et al., 2007).

Atlantic salmon (Salmo salar L.) is an important recreational and commercial species found on both sides of the Atlantic Ocean, but over the past few decades many wild populations have experienced a significant decline (Parrish et al., 1998). Al toxicity in acidified water has been identified as a major contributor to this decrease (Kroglund et al., 2007; McCormick et al., 2009). An increase in Al concentration in water has been linked to an increase in Al accumulation in the gills (Kroglund et al., 2008). Al is known to affect the function of the gills in both parr and smolts, but there appears to be increased sensitivity to this chemical stress in smolts (Monette and McCormick, 2008). This effect is likely due to enhanced stress responsiveness, often seen as elevated plasma glucose and cortisol levels, as the fish adapt to seawater (Monette and McCormick, 2008; Monette et al., 2010). One way in which exposure to $\mathrm{Al}$ toxicity can hinder adaptation is through the loss of ion regulatory ability brought about by a decrease in gill $\mathrm{Na}^{+}, \mathrm{K}^{+}$ATPase (NKA) activity, an enzyme required for seawater tolerance (Nilsen et al., 2010). The negative influences of $\mathrm{Al}$ on ion secretion during smoltification may therefore contribute to decreased survival in salmon at sea. 
In addition to physiological adaptations associated with smoltification, the brain undergoes major structural and chemical changes. These arise because of the neuroendocrine and behavioral changes associated with olfactory imprinting that are essential for migration to the ocean and return to natal streams (Ebbesson et al., 1996a; Ebbesson et al., 1996b; Ebbesson et al., 2003; Ebbesson et al., 2007; Ebbesson et al., 2011; Stefansson et al., 2008). The physiological effects of stress also have an impact on behavior, through modification or impairment of signaling pathways that control behaviors such as feeding and aggression (Barton, 2002). During the critical smolting phase, Atlantic salmon have to adapt their behavior to cope with the transition from freshwater to the marine environment, and an additional stress imposed by Al toxicity could impair their ability to adapt to this transition successfully. Because behavioral changes are mediated by chemical pathways in the brain, exposure to a stressor will likely affect the organization or properties of specific neural circuitry that produce behavior (Kolb et al., 2003). Neurogenic differentiation factor (NeuroD) is a member of the family of proneural genes that regulates and controls neural differentiation (Kiefer et al., 2005). Neurogenesis, which includes proliferation, migration, differentiation and survival of neurons, is an integral step in learning and memory that is modulated by stress (Banasr and Duman, 2007). NeuroD protein and mRNA have been used as neural differentiation markers in vertebrates (see Dufton et al., 2005) including fish (Mueller and Wullimann, 2002; Mueller and Wullimann, 2003). Therefore, stress-induced changes in learning could be linked to modifications in neurogenesis through differential expression of NeuroD. As in zebrafish, it is possible that salmon possess multiple NeuroD transcription factors, so for the purposes of this study we investigated changes in the expression of one specific NeuroD transcription factor, NeuroD1 (Liao et al., 1999).

Several behaviors that influence how animals make decisions are underpinned by cognition, a process that spans the way an animal perceives current information, internalizes this and then uses learning and memory processes to determine which behavioral response is most appropriate (Shettleworth, 2010). Learning and memory processes help to support navigation, which is an important behavior for many fish species (Braithwaite and de Perera, 2006; Odling-Smee et al., 2008). As juveniles, Atlantic salmon need to be able to find their way around their river; as smolts, they need to migrate to sea and then, after many months at sea, as adults they return to their natal river or stream to spawn (Braithwaite and de Perera, 2006; Hansen et al., 1993). To be able to complete these different kinds of navigation, salmon need to learn and remember different aspects of their environment. If exposure to $\mathrm{Al}$ in acidified water impairs cognitive capacity, this will likely affect the survival of these fish.

The present study was designed to test the effects of chronic exposure to $\mathrm{Al}$ in acidified water on Atlantic salmon. Al concentration in the gills was determined to document $\mathrm{Al}$ exposure. Plasma glucose and cortisol levels were measured to assess physiological stress. We measured gill NKA activity to assess the physiological effect of the treatment, as Al toxicity is known to reduce NKA activity in salmon smolts (Monette and McCormick, 2008; Nilsen et al., 2010). A simple maze task was used to investigate whether $\mathrm{Al}$ exposure affects cognitive ability. We predicted that exposure to an Al-enriched environment would have a negative impact on learning through decreased accuracy in a spatial task. Finally, to investigate potential changes within the brain, we measured neural plasticity through expression of the transcription factor NeuroD in the telencephalon.

\section{MATERIALS AND METHODS Fish and rearing conditions}

In February 2010, 250 Atlantic salmon parr were obtained from a wild anadromous strain originating from River Vosso in Norway. They were transported to the Aquatic Laboratory at Bergen High Technology Center and maintained in two $1 \mathrm{~m}^{2}$ indoor tanks with a rearing volume of 5001 supplied with flow-through freshwater at $101 \mathrm{~min}^{-1}, \mathrm{pH}$ adjusted (6.9-7.1) and kept at $8^{\circ} \mathrm{C}$. The fish were exposed to a simulated natural photoperiod $\left(60^{\circ} 25^{\prime} \mathrm{N}\right)$ and fed a commercial dry diet (T. Skretting A/S, Stavanger, Norway) continuously during the photo-phase.

The experiments were given ethical approval by the Norwegian Animal Research Authority (reference no. 1027636).

\section{Treatment setup}

On 20 March 2010, 104 pre-smolt salmon (mean mass of $22.8 \pm 0.3 \mathrm{~g}$ and mean fork length of $12.8 \pm 0.1 \mathrm{~cm}$; randomly sampled from the original 250) were individually marked using micro PIT tags (Nonatec, Lutronic International, Luxembourg) under anesthesia using $100 \mathrm{mgl}^{-1}$ buffered tricaine methanosulphonate (MS-222; Sigma-Aldrich, St Louis, MO, USA). The fish were allowed to recover for 4 weeks before being placed into two different treatments on 19 April: Acid-Al and control (no additional stressor). Both treatment groups consisted of two replicate tanks with 20 or 22 fish in each. $\mathrm{Al}\left[\mathrm{AlCl}_{3}\left(\mathrm{H}_{2} \mathrm{O}\right)_{6}\right.$ dissolved in $\left.24 \mathrm{mmoll}^{-1} \mathrm{HCl}\right]$ and acid $\left(1.2 \mathrm{moll}^{-1} \mathrm{HCl}\right)$ were added by peristaltic pumps continuously to one header tank and mixed with control water, creating the Acid-Al water quality. Thus, increased concentration of $\mathrm{AlCl}_{3}$ and decreased $\mathrm{pH}$ were the only differences between the treatments. Fish were maintained this way for the entire experiment.

\section{Water sampling and speciation of $\mathrm{Al}$}

It was expected that some of the Al added as Al cations to the water was transformed and thus would be present in less bioavailable particulate and colloidal forms (Teien et al., 2006). To obtain information about the final distribution of $\mathrm{Al}$ species and the $\mathrm{Al}$ exposure, on 28 April both the total concentration of $\mathrm{Al}$ and the Al speciation in the Acid-Al exposure and the control water were determined. The water in the tanks was fractionated with respect to size (molecular mass) and charge using in situ $0.45 \mu \mathrm{m}$ membrane filtration and ultra filtration (Amicon H1P1020 hollow fibre operating at $69-103 \mathrm{kPa}$, nominal molecular mass cut-off $10 \mathrm{kDa}$; Danvers, MA, USA) and cation chromatography (Amberlite) (Teien et al., 2004). Fractionated water was acidified and $\mathrm{Al}$ was determined using inductively coupled plasma atomic emission spectrometry (ICP-AES). Thus, the concentration of different Al species was derived and defined according to the methods applied: Al tot, total dissolved Al in unfiltered samples; particulate $\mathrm{Al}$, total concentration of $\mathrm{Al}$ associated with particles, i.e. larger than $0.45 \mu \mathrm{m}$; colloidal or high molecular mass (HMM) $\mathrm{Al}$, total concentration of HMM Al species and $\mathrm{Al}$ associated with colloids, i.e. molecular mass ranging from $10 \mathrm{kDa}$ to $0.45 \mu \mathrm{m}$; low molecular mass (LMM) Al, total concentration of LMM Al species, i.e. ultrafiltered (nominal molecular mass less than

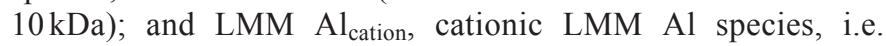
ultrafiltered (nominal molecular mass less than $10 \mathrm{kDa}$ ), retained by Amberlite ( $\mathrm{Na}$ form).

The water quality in the tanks was controlled by monitoring $\mathrm{pH}$, temperature and conductivity. In addition, major cations $\left(\mathrm{Ca}^{2+}, \mathrm{Na}^{+}\right.$, $\left.\mathrm{Si}^{+}, \mathrm{Mg}^{2+}\right)$ and anions $\left(\mathrm{SO}_{4}{ }^{2-}, \mathrm{Cl}^{-}, \mathrm{F}^{-}, \mathrm{NO}_{3}{ }^{-}\right)$were analyzed in the collected water samples (Teien et al., 2004). 
Table 1. Water quality in control and Acid-Al $(N=3)$ treatments

\begin{tabular}{|c|c|c|c|c|c|c|c|c|c|c|c|c|}
\hline & $\begin{array}{c}\text { Temperature } \\
\left({ }^{\circ} \mathrm{C}\right)\end{array}$ & $\begin{array}{l}\text { Conductivity } \\
\left(\mathrm{mS} \mathrm{m}^{-1}\right)\end{array}$ & $\begin{array}{l}\mathrm{pH} \\
\mathrm{pH}\end{array}$ & $\begin{array}{c}\text { TOC } \\
\left(\mu \mathrm{moll}^{-1}\right)\end{array}$ & $\begin{array}{c}\mathrm{Cl}^{-} \\
\left(\mu \mathrm{moll}^{-1}\right)\end{array}$ & $\begin{array}{c}\mathrm{NO}_{3}^{-} \\
\left(\mu \mathrm{moll}^{-1}\right)\end{array}$ & $\begin{array}{c}\mathrm{SO}_{4}^{2-} \\
\left(\mu \mathrm{moll}^{-1}\right)\end{array}$ & $\begin{array}{c}\mathrm{Ca} \\
\left(\mu \mathrm{moll}^{-1}\right)\end{array}$ & $\begin{array}{c}\mathrm{K} \\
\left(\mu \mathrm{moll}^{-1}\right)\end{array}$ & $\underset{\left(\mu \mathrm{moll}^{-1}\right)}{\mathrm{Mg}}$ & $\begin{array}{c}\mathrm{Na} \\
\left(\mu \mathrm{moll}{ }^{-1}\right)\end{array}$ & $\left.\begin{array}{c}\mathrm{Si} \\
(\mu \mathrm{moll} \\
-1\end{array}\right)$ \\
\hline Control & $7.9 \pm 0$ & $3.5 \pm 0$ & 6.7 & $174.8 \pm 16$ & $155^{\mathrm{a}}$ & $1.61^{a}$ & $30.18^{a}$ & $49.9 \pm 5.0$ & $56.27 \pm 7.7$ & $16.5 \pm 0$ & $160.9 \pm 0$ & $71.2 \pm 10$ \\
\hline Acid-Al & $8.1 \pm 0$ & $3.8 \pm 0$ & 5.7 & $174.8 \pm 16$ & $206 \pm 0.0$ & $1.61 \pm 0$ & $29.15 \pm 0$ & $47.4 \pm 0$ & $46.04 \pm 0$ & $16.5 \pm 0$ & $160.9 \pm 0$ & $78.3 \pm 0$ \\
\hline
\end{tabular}

Data are means \pm s.d. TOC, total organic carbon.

${ }^{a} N=1$.

The control water quality was characterized with a $\mathrm{pH}$ of 6.75 and was relatively low in ionic strength $\left(3.5 \mathrm{mS} \mathrm{m}^{-1}\right.$ in conductivity and $49.9 \mu \mathrm{mol} 1^{-1}$ of $\mathrm{Ca}$; Table 1$)$. In the control water the $\mathrm{Al}$ concentration was $1.46 \mu \mathrm{mol} 1^{-1}$, where $70 \%$ was present as colloidal and not bioavailable Al species (Table 2). The concentration of $\mathrm{Al}$ cations was less than $0.04 \mu \mathrm{mol} 1^{-1}$ in the control water. Due to the addition of $\mathrm{AlCl}_{3}$ and acid, the $\mathrm{pH}$ decreased to 5.7 and the concentration of $\mathrm{Al}$ increased from 1.46 to $3.29 \mu \mathrm{mol} 1^{-1}$ in the Acid-Al exposure. This is similar to the concentration of the $\mathrm{Al}$ in several rivers in Norway and thus is highly relevant, with both the colloidal Al fraction being less bioavailable (Teien et al., 2005) and the LMM Al fraction being increased in the Acid-Al water. The concentration of LMM Al cations in the Acid-Al water was $0.38 \pm 0.09 \mu \mathrm{mol}^{-1}$ (mean \pm s.d.).

\section{Sampling}

Two weeks after the start of the treatment and 1 day prior to the behavior trials, 10 fish from each treatment group were quickly dip-netted and anesthetized in $200 \mathrm{mg} \mathrm{l}^{-1} \mathrm{MS}-222$. Individual fish were weighed (wet mass in $\mathrm{g}$ ) and measured (fork length in $\mathrm{cm}$ ), and then blood was collected from the caudal vessels with heparinized tuberculin syringes. Blood was subsequently centrifuged $\left(1500 \mathrm{~g}, 10 \mathrm{~min}, 4^{\circ} \mathrm{C}\right)$, and plasma aliquots were frozen on dry ice. One drop of blood was used for glucose measurement (see below). One gill arch was placed in a preweighed scintillation vial for gill Al measurements. The day after behavior trials, another 10 fish from each treatment group were sampled following the same procedure as above. Brains were rapidly dissected and immediately placed in RNAlater (Ambion, Austin, TX, USA) and stored at $-80^{\circ} \mathrm{C}$ for subsequent quantification of telencephalic NeuroD1 mRNA expression. One gill arch was placed in ice-cold SEI buffer $\left(250 \mathrm{mmoll}^{-1}\right.$ sucrose, $10 \mathrm{mmoll}^{-1}$ EDTA, $50 \mathrm{mmoll}^{-1}$ imidazole, $\mathrm{pH} 7.3$ ) and frozen for determination of NKA activity. Telencephalic NeuroD1 mRNA expression and NKA activity samples were taken after behavioral testing to determine how physiology and neural plasticity after the maze challenge were affected by Acid-Al. All samples were stored at $-80^{\circ} \mathrm{C}$ until assayed.

\section{Gill aluminum}

The concentration of $\mathrm{Al}$ in gills $(N=10)$ was determined by the method of Teien et al. (Teien et al., 2006), and refers to Al precipitated on the gill surface, $\mathrm{Al}$ incorporated in the gill cells and $\mathrm{Al}$ associated with mucus on gills.

\section{Plasma glucose}

Plasma glucose $\left(\mathrm{mmoll}^{-1}\right)$ levels $(N=10)$ were determined immediately after blood collection using a portable i-STAT clinical analyser (Harrenstien et al., 2005). Values were corrected for the temperature difference between ambient water temperature and the temperature-adjusted $\left(37^{\circ} \mathrm{C}\right)$ values displayed by the instrument in accordance with the i-STAT procedure (Eliason et al., 2007) and ISTAT analyzer (Abbot Norge AS, Fornebu, Norway). Analytical cassettes of the type EC8+ were used for analyses of plasma glucose $\left(\mathrm{mmol} \mathrm{1}^{-1}\right)$.

\section{Plasma cortisol}

Cortisol $(N=10)$ was measured using a radioimmunoassay in a 96well plate. All wells except the 'non-specifics' received $100 \mu \mathrm{l}$ cortisol antibody [Cortisol Antibody[xm210] monoclonal and IgG purified (Abcam, Cambridge, MA, USA); 1:2000 in $50 \mathrm{mmoll}^{-1}$ $\left.\mathrm{NaHCO}_{3}, 50 \mathrm{mmoll}^{-1} \mathrm{NaH}_{2} \mathrm{CO}_{3}, 0.02 \% \mathrm{NaN}_{3}, \mathrm{pH} 9.6\right]$ and were incubated overnight at $4^{\circ} \mathrm{C}$. The following day, the plates were washed three times with $200 \mu \mathrm{lwell}^{-1}$ wash buffer $\left(100 \mathrm{mmoll}^{-1}\right.$ Tris, $0.9 \% \mathrm{NaCl}, 0.02 \% \mathrm{NaN}_{3}$ ). Subsequently, non-specific sites were blocked by the addition of $100 \mu \mathrm{l}$ blocking buffer $\left(100 \mathrm{mmoll}^{-1}\right.$ Tris, $0.9 \% \mathrm{NaCl}, 0.02 \% \mathrm{NaN}_{3}, 0.25 \%$ normal calf serum) to each well. Plates were covered and incubated for $1 \mathrm{~h}$ at $37^{\circ} \mathrm{C}$. Subsequently, $10 \mu \mathrm{l}$ of standard (4-2048 pg cortisol $10 \mu \mathrm{l}^{-1}$ assay buffer containing $100 \mathrm{mmoll}^{-1}$ Tris, $0.9 \% \mathrm{NaCl}, 0.1 \%$ 8-anilino-1-naphthalenesulfonic acid, $0.02 \% \mathrm{NaN}_{3}$ ) or $10 \mu \mathrm{l}$ of undiluted plasma was added to designated wells. Non-specifics and $\mathrm{B}_{0}$ received $10 \mu \mathrm{l}$ assay buffer. After the addition of standards and samples, $90 \mu \mathrm{l}(333 \mathrm{~Bq})$ of ${ }^{3} \mathrm{H}-$ hydrocortisone (PerkinElmer, Waltham, MA, USA, 1:10,000 in assay buffer) solution was added to all wells. Plates were incubated overnight at $4^{\circ} \mathrm{C}$. The plates were then washed three times with wash buffer. After the final wash step, all wells received $200 \mu \mathrm{l}$ of Optiphase hisafe-3 scintillation liquid (PerkinElmer) and were covered. Beta-emission was quantified by a 3 min count per well using a Microbeta Plus (Wallac/PerkinElmer, Waltham, MA, USA). The cortisol assay had inter- and intra-assay variations of 12.5 and $3.5 \%$, respectively. The cortisol antibody had the following crossreactivities: cortisol $100 \%$; 11-deoxycortisol $0.9 \%$; prednisolone $5.6 \%$; corticosterone $0.6 \% ; 11$-deoxycorticosterone, progesterone, 17-hydroxyprogesterone, testosterone, estradiol and estriol all $<0.01 \%$ (Gorissen et al., 2012).

\section{Gill NKA activity}

Gill NKA activity $(N=10)$ was determined by the method of McCormick (McCormick, 1993). Briefly, this kinetic assay utilizes

Table 2. Water concentrations of different Al fractions in control and Acid-Al $(N=3-6)$ treatments

\begin{tabular}{|c|c|c|c|c|c|}
\hline & Al total $\left(\mu \mathrm{mol} \mathrm{I}^{-1}\right)$ & Particulate $\mathrm{Al}\left(\mu \mathrm{mol} \mathrm{I}{ }^{-1}\right)$ & Colloidal $\mathrm{Al}\left(\mu \mathrm{mol} \mathrm{I} \mathrm{I}^{-1}\right)$ & $\operatorname{LMM~Al}\left(\mu \mathrm{mol} \mathrm{I}^{-1}\right)$ & LMM Al cations $(\mu \mathrm{mol} \mathrm{I-1})$ \\
\hline Control & $1.46 \pm 0.01$ & $0.03 \pm 0.02$ & $1.03 \pm 0.06$ & $0.40 \pm 0.05$ & $<0.04$ \\
\hline Acid-Al & $3.29 \pm 0.10$ & $0.03 \pm 0.08$ & $1.96 \pm 0.17$ & $1.33 \pm 0.13$ & $0.38 \pm 0.09$ \\
\hline
\end{tabular}

Data are means \pm s.d. LMM, low molecular mass. 
the hydrolysis of ATP, which is enzymatically coupled to the conversion of $\mathrm{NADH}$ to $\mathrm{NAD}^{+}$by pyruvate kinase and lactic dehydrogenase with or without the addition of ouabain, the specific inhibitor of NKA. Readings were taken at $340 \mathrm{~nm}$ for $10 \mathrm{~min}$ at $25^{\circ} \mathrm{C}$. Protein in homogenate was determined by a bicinchoninic acid method (Smith et al., 1985). The ouabain-sensitive, $\mathrm{K}^{+}$-dependent NKA-specific activity is expressed in $\mu \mathrm{mol} \mathrm{ADPh}^{-1} \mathrm{mg}^{-1}$ protein.

RNA isolation, cDNA synthesis and real-time quantitative PCR The whole brain $(N=10)$ was thawed in RNAlater Ice (Ambion) following the manufacturer's instructions, and the telencephalon was isolated under a dissecting microscope by cutting away the olfactory bulbs and then cutting vertically between the telencephalon and the hypothalamus. Total RNA was then directly isolated from the telencephalon by phenol-chloroform extraction using TRI Reagent (Sigma-Aldrich) as outlined by Chomczynski (Chomczynski, 1993). Total RNA concentration and purity was determined by the NanoDrop ND-1000 UV-Vis Spectrophotometer (NanoDrop Technologies, Wilmington, DE, USA) and the RNA integrity was evaluated with the Agilent 2100 Bioanalyzer using the RNA 6000 Nano LabChip kit (Agilent Technologies, Palo Alto, CA, USA). Total RNA was treated with the TURBO DNA-free kit (Ambion, Austin, TX, USA) and cDNA reversely transcribed using $2 \mu \mathrm{g}$ total RNA and Oligo $d\left(T_{15}\right)$ in conjunction with the SuperScript III kit (Invitrogen, Carlsbad, CA, USA) following the manufacturer's instructions.

Real-time quantitative PCR was conducted with gene-specific primers in conjunction with SYBR Green Master Mix (Applied Biosystems, Foster City, CA, USA) using the MJ Research Chromo 4 System Platform (Bio-Rad Laboratories, Hercules, CA, USA). The forward and reverse primers for salmon brain NeuroD1 (GenBank accession no. BT058820) were: CAATGGACAGCTCCCACATCT (forward) and CCAGCGCACTTCCGTATGA (reverse). For the assays, the thermal cycling protocols contained $5 \mu \mathrm{l}$ cDNA (200ng RNA), $200 \mathrm{nmoll}^{-1}$ of each primer and $12.5 \mu \mathrm{l}$ SYBR Green Master Mix in a total volume of $25 \mu l$. The thermal cycling protocol consisted of $10 \mathrm{~min}$ at $95^{\circ} \mathrm{C}$ followed by 45 cycles at $95^{\circ} \mathrm{C}$ for $15 \mathrm{~s}$ and $60^{\circ} \mathrm{C}$ for $1 \mathrm{~min}$. Melt-curve analysis verified that the primer sets for each Q-PCR assay generated one single product and no primer-dimer artifacts. For each assay, triplicate twofold cDNA dilution series made from different exposure groups were used to determine amplification efficiencies $(E)$, calculated as the slope from the plot of log cDNA concentration versus threshold cycle $\left(C_{\mathrm{t}}\right)$ values using the following formula: $E=10^{-1 / \text { slope }}$. This efficiency was used to correct for differences in amplification efficiency when calculating gene expression according to Pfaffl (Pfaffl, 2004). Expression is presented as relative to the endogenous reference gene ribosomal protein L 23 (RPL 23), which did not vary between treatments in the present study. The RPL 23 forward primer was ATGCTGCCAGCATTTGAAGCAATCCT and the 23 RPL reverse primer was CTTTACATCATCTCTGTCAAGGGCATCAA.

\section{Maze trial procedure}

After 15 days in the treatment tanks, behavioral trials started (control, $N=40$; Acid-Al, $N=42$ ). Learning ability was assessed using a maze that was placed inside the test tanks (similar to the holding tanks) that either contained Acid-Al treated water or control freshwater at a depth of $50 \mathrm{~cm}$. Fish were tested in the same water as their home tanks: fish exposed to Acid-Al were always run in the Acid-Al conditions for the maze, and control fish were tested in control water conditions. The maze was raised up on a platform creating a water depth of $15 \mathrm{~cm}$ inside the maze, providing a place of shelter and shade beneath the maze. The maze consisted of a central arena that opened out to four arms that each led to a doorway (Fig. 1). There were three 'false' exits and one 'true' exit leading out into the open area in the test tank. The 'true' exit was marked with a small black circular piece of plastic (radius $1.5 \mathrm{~cm}$ ) attached to the wall next to the exit.

Fish were tested individually. Each day, fish were netted out of their holding tank, scanned using a hand-held PIT-tag reader for identification and then placed in a transparent start cylinder (radius $8 \mathrm{~cm}$ ) in the center of the maze. After $10 \mathrm{~s}$ the cylinder was lifted remotely and the fish was free to explore the maze. Trials ended after $5 \mathrm{~min}$, or when the fish escaped successfully. Once fish had left the maze they were allowed to swim freely around the exterior of the maze to help provide a potential social stimulus for fish still to be tested (although the sides of the central arena were opaque, the doorways at each of the false exits were transparent). This methodology is similar to that of Sovrano et al. (Sovrano et al., 2002), where the motivation for fish to leave the maze was social reinstatement. As the maze was brightly illuminated, the main motivator to leave the maze was probably the aversion to bright light, promoting escape into the main tank where the fish could find shade and shelter underneath the maze apparatus. Testing of fish within each tank was randomized; no fish was selected as the first fish more than once across the different test trials. Fish were returned to their holding tank after all fish in that tank had been screened in the maze. No fish attempted to re-enter the maze. The maze was taken out of the tank after all the fish from a tank had been tested. This made it easier to net and remove the fish. During this stage, we also flushed the tank with clean water before the start of the next block of trials.

Fish were tested once per day in two blocks of trials: block 1, trials $1-3$, followed by a 2 day break, and then block 2, trials 4-6. All trials were filmed using a camera positioned over the top of the test tanks. The videos were screened after the maze trials were

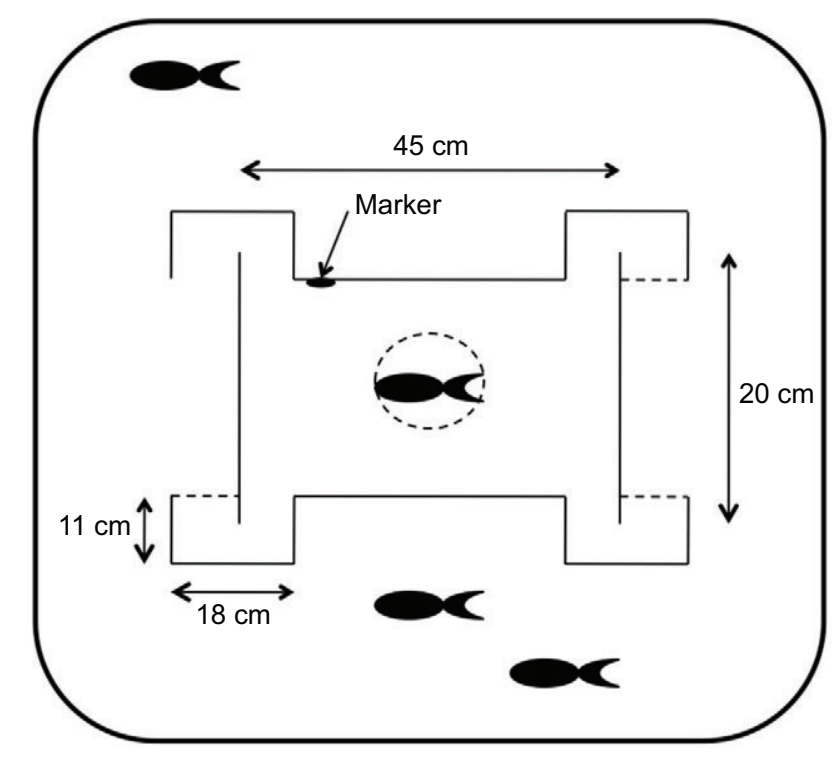

Fig. 1. Plan view (not drawn to scale) of the maze with test fish inside the isolation tube. The maze was raised up on a platform, creating a water depth of $15 \mathrm{~cm}$ inside the maze. Each exit (arm) was enclosed but the central arena was open. Solid lines indicate opaque walls that were used to minimize external cues; dashed lines are transparent walls. 
Table 3. Summary of physiological parameters in control and Acid-Al fish

\begin{tabular}{lccc}
\hline Physiological parameter & Control & Acid-Al & $P$ \\
\hline Gill Al $\left(\mu \mathrm{mol} \mathrm{g}^{-1}\right.$ dry mass) & $0.11 \pm 0.01$ & $2.00 \pm 0.15$ & $<0.01$ \\
Gill NKA activity $\left(\mu \mathrm{mol} \mathrm{ADP} \mathrm{h}^{-1} \mathrm{mg}^{-1}\right.$ protein) & $14.6 \pm 1.6$ & $9.3 \pm 2.4$ & $<0.01$ \\
Plasma glucose $\left(\mathrm{mmol}^{-1}\right.$ ) & $5.3 \pm 0.5$ & $7.7 \pm 2.8$ & 0.01 \\
Plasma cortisol $\left(\mathrm{ng} \mathrm{ml}^{-1}\right)$ & 14.5 & 43.0 & $<0.01$ \\
\hline
\end{tabular}

All values are reported as means \pm s.d. excluding the plasma cortisol levels, which are median values.

completed and the total number of arms visited during each trial was recorded using Etholog v2.2.5 (Ottoni, 2000). All videos were analyzed with the observer blind to whether a fish was a control or Acid-Al treated fish.

\section{Statistical analysis}

Data were tested for equality of variance and were transformed when there was heterogeneity of variance across the groups being compared. If data did not meet the assumptions of normality and homoscedasticity, non-parametric tests were applied. Mass and fork length, neuroD1 mRNA expression and NKA activity were compared between Acid-Al and control groups using unpaired Student's $t$-tests. Gill Al levels were $\log _{10}$-transformed before these data were compared using a Student's $t$-test. Reciprocal transformation was used for the plasma glucose levels before these data were compared using a Student's $t$-test. Plasma cortisol levels were compared between Acid-Al and control groups using a Mann-Whitney $U$-test. For the behavioral data, there was no difference in the performance of fish in the maze from replicate tanks $\left(F_{1,455}=3.33, P=0.07\right)$, thus tanks were pooled for behavioral analysis. The number of arms entered was square-root transformed before being compared using a repeated-measures ANOVA with treatment as a factor. The data were compared across two blocks of three trials, the first block covering trials $1-3$ and the second block trials 4-6. Fish were excluded if they never learned to leave the maze and just froze during a trial without visiting any exits (excluded: 11 control, 0 Acid-Al). Freezing is not an uncommon response for salmon, and we believe that the zero value for the AcidAl fish arose because these fish were more active. The increased activity levels exhibited by the Acid-Al fish may be due to increased levels of stress, resulting in all the Acid-Al fish visiting at least one exit. For the behavior data, variation around the mean is represented as s.e.m. For all other data, variation around the mean is represented as the s.d. All analyses were conducted in StatView (version 5.0.1) and significance was tested at $\alpha=0.05$.

\section{RESULTS \\ Mass and length}

There was no significant difference in mass (Acid-Al $=29.6 \pm 4.3 \mathrm{~g}$, control $=29.0 \pm 3.5 \mathrm{~g}$; $t$-test: $t_{1,18}=0.36, P=0.72$ ) or fork length (Acid$\mathrm{Al}=14.4 \pm 0.8 \mathrm{~cm}$, control $=14.2 \pm 0.6 \mathrm{~cm}$; $t$-test: $\left.t_{1,18}=0.88, P=0.39\right)$ of fish after 2 weeks of treatment.

\section{Physiology}

Gill aluminum

Gill Al levels were higher in the Acid-Al exposed fish compared with the control fish ( $t$-test: $t_{1,17}=23.04, P<0.01$; Table 3$)$.

\section{Plasma glucose}

Fish from the Acid-Al treatment were hyperglycemic, whereas those from the control treatment were not $\left(t\right.$-test: $t_{1,18}=3.83, P=0.01$; Table 3).

\section{Plasma cortisol}

Fish from the Acid-Al treatment had higher plasma cortisol levels than control fish (Mann-Whitney: $U=11.0, P<0.01$; Table 3 ).

\section{NKA activity}

Fish from the Acid-Al treatment had significantly lower NKA activity than control fish ( $t$-test: $t_{1,18}=5.82, P<0.01$; Table 3 ).

\section{NeuroD1 mRNA}

Fish from the Acid-Al treatment had significantly lower neuroD1 mRNA levels (relative to RPL 23) than control fish (Acid$\mathrm{Al}=4.6 \pm 1.4$, control $=6.9 \pm 2.3$; $t$-test: $t_{1,18}=2.67, P=0.02$; Fig. 2 ).

\section{Behavior}

For both the control and Acid-Al fish, the average number of arms visited decreased across trials, suggesting that performance improved as the fish became more experienced with the maze (ANOVA: $\left.F_{5,407}=3.57, P<0.01\right)$. Examining the behavior of the fish across the two blocks (block 1: trials 1-3 and block 2: trials 4-6) revealed a significant effect of treatment across block 2 trials, with Acid-Al fish making more mistakes on average than control fish (Acid$\mathrm{Al}=3.6 \pm 0.3$, control $=2.9 \pm 0.2$, ANOVA: $F_{1,67}=4.23, P=0.04$; Fig. 3 ). There was no effect of treatment across block 1 trials (ANOVA: $\left.F_{1,68}=0.03, P=0.86\right)$.

\section{DISCUSSION}

Two weeks of exposure to $\mathrm{Al}$ in acidified water caused $\mathrm{Al}$ accumulation on the gills and impaired the spatial learning ability of smolting Atlantic salmon. The Acid-Al-exposed fish made more mistakes, indicating that acquisition of the task was inhibited, and had reduced neural plasticity indicators in their forebrain. Exposure to Al imposed a physiological stress, as levels of plasma glucose

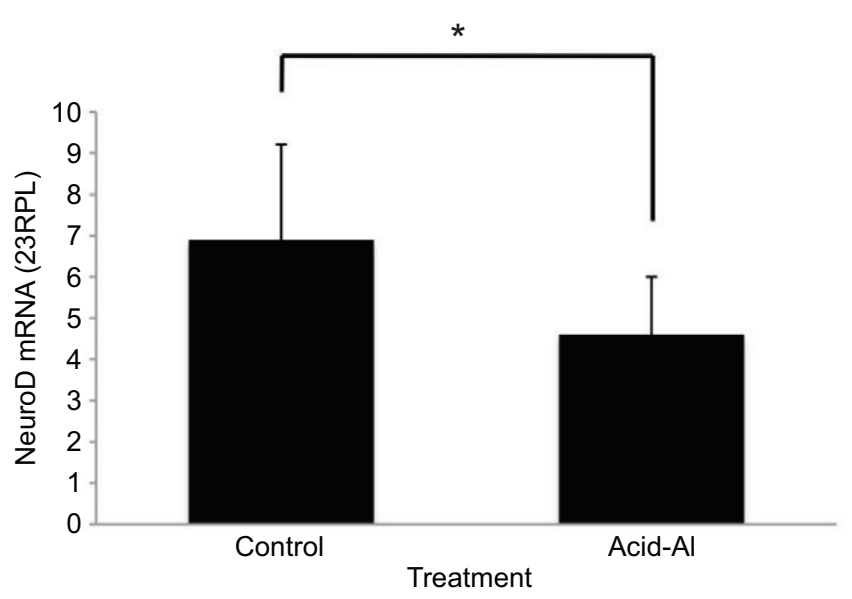

Fig. 2. Relative NeuroD1 mRNA expression in the telencephalon for control and Acid-Al fish (mean \pm s.d.). *Significant difference between treatments $(P<0.05)$. 


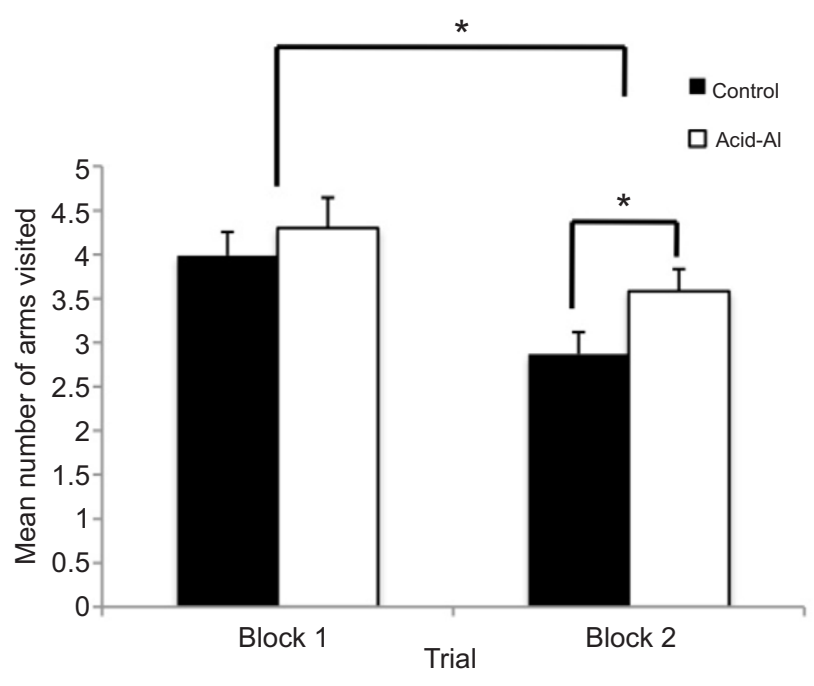

Fig. 3. The average number of maze arms visited for control and Acid-Al fish in block 1 and block 2 of the experiment (mean \pm s.e.m.). *Significant difference between blocks or treatments $(P<0.05)$.

and cortisol increased. Together, these data suggest that exposure to Al toxicity in acidified water has a negative impact on both the brain and learning behavior in salmon. Such an effect is likely to have a negative influence on the ability of the fish to cope with the transition from freshwater to the marine environment, a time when the fish need to perform critical behaviors such as predator avoidance, social interactions and navigation (McCormick et al., 1998; Ebbesson and Braithwaite, 2012). Furthermore, it is possible that the reduced forebrain neural plasticity and cognitive deficit at the critical smolt stage also affect imprinting, by altering the olfactory-telencephalic plasticity associated with smoltification (Ebbesson et al., 1996a; Ebbesson et al., 2003; Folgueira et al., 2004). Memories of the natal stream formed during imprinting are later used to return as adults (Hasler and Scholz, 1983; Yamamoto et al., 2010), and thus impaired imprinting could have a profound impact on return success. Such behavioral processes are likely to involve the area of the brain involved in spatial learning and memory, namely the dorsolateral area of the telencephalon (Ebbesson and Braithwaite, 2012).

We predicted that fish exposed to a prolonged period of elevated Al would be less accurate in the maze task than control fish. While there was an overall decrease in the number of mistakes made as the experiment progressed for fish from both groups, salmon from the Acid-Al treatment made more mistakes than control fish. It is possible that poorer learning in Acid-Al fish is linked to the observed decrease in neural plasticity, in line with a lower level of NeuroD1 mRNA expression in the telencephalon. The relationship between NeuroD1 gene expression and neurogenesis during early development has been identified in fish (Korzh et al., 1998; Mueller and Wullimann, 2003), and it is well established that neurogenesis in the telencephalon is known to occur throughout adult life in fish (Lema et al., 2005; Zupanc, 2008; von Krogh et al., 2010). The telencephalon is one of the most sensitive regions to stress-induced changes in the fish brain (Sørensen et al., 2011). A possible explanation for the reduced NeuroD1 expression in the telencephalon of Acid-Al fish was the increased levels of stress, shown by the higher levels of plasma glucose and cortisol in this group of fish before testing in the maze. The functional consequences of stress are dependent on the magnitude and duration of the stressor, but chronic stress is known to have detrimental effects on learning and memory (Conrad, 2010). Therefore, decreased neural plasticity suggested by a decrease in NeuroD1 mRNA expression may have mediated some of the observed behavioral changes.

Both cortisol and plasma glucose levels have been used as indicators of physiological stress in fish (Barton, 2002; Barton and Iwama, 1991; Begg and Pankhurst, 2004; Wendelaar Bonga, 1997). When cortisol is released in response to a stressful event, it mobilizes fuels such as glucose to bring the fish back to homeostasis (Gregory and Wood, 1999). In the present study, Acid-Al fish had higher levels of both plasma glucose and cortisol than control fish, suggesting a higher stress level due to activation of the endocrine hypothalamic-pituitary-interrenal (HPI) axis. The effects of acidification on Atlantic salmon have been studied and, similarly, it was found that low $\mathrm{pH}$ was strongly correlated with negative physiological effects (Liebich et al., 2011). Thus in the present study, fish exposed to Al toxicity in acidic water will have experienced high allostatic load through physiological changes associated with the HPI axis, which may have led to the observed changes in learning behavior. In addition, exposure to Al toxicity lowered NKA activity in the gill. This is similar to the results of another study in salmon that found negative impacts on ion-regulatory development during smoltification (Nilsen et al., 2010). While Al impairment of ion regulatory development is detrimental for a smolt and has been implicated in low rates of returning adults (Kroglund and Finstad, 2003; Monette et al., 2008), a recent study has shown that ion regulatory capacity can partially recover following episodic acidification and $\mathrm{Al}$ exposure (Kroglund et al., 2012). In the present study, the mechanisms through which Al exposure affected gill condition are unknown; Al toxicity may have acted directly on NKA activity, or it may have acted indirectly by stimulating the HPI axis and inducing changes in NKA activity.

Our data showing impaired learning in Acid-Al treated fish add a new consideration in terms of how Al toxicity in acidified water affects salmon. The effect appears to extend beyond physiological changes to also altering learning behavior. It is known that smolts have a heightened sensitivity to $\mathrm{Al}$ in acidified water compared with parr (Monette and McCormick, 2008). In parr, many of the smoltrelated parameters, such as neural plasticity, hormones and NKA activity, are at baseline levels, thus making it difficult to detect impacts on them. We chose to test the fish during a significant developmental period in their life cycle because the toxicity of $\mathrm{Al}$ in freshwater is enhanced, potentially leading to detrimental effects later on in life. Certainly, we found effects of $\mathrm{Al}$ exposure in terms of increased levels of glucose and cortisol. Taken on its own, however, it is not clear whether an increase in allostatic load, brought about by altered stress physiology, is causing distress or eustress in the fish (Korte et al., 2007; Korte et al., 2009). With the addition of our data on behavioral impairment and decreased neural plasticity, a decrease in cognitive ability suggests that the impact of Al toxicity is playing a negative role, causing distress in the exposed fish. These kinds of negative effects may have consequences for the ability of smolts to imprint on their natal streams (Yamamoto et al., 2010); it has been established that the parr-smolt transformation is a critical period for neural development, including cell differentiation and proliferation (Ebbesson et al., 1996b; Ebbesson et al., 2003; Ebbesson et al., 2007; Ebbesson et al., 2011). Olfactory imprinted memory is formed during smolting and the loss of neural plasticity could therefore impair the ability of Atlantic salmon to return to their natal stream (Dittman et al., 1996).

The negative impact of Al toxicity on cognitive ability during such a critical period has implications for how we can make 
management decisions for fish that are at a high risk of exposure. Further studies investigating the neural and behavioral consequences of $\mathrm{Al}$ toxicity are needed to determine the breadth of these impacts. Taking the various negative effects together, salmon exposed to $\mathrm{Al}$ in acidic conditions appear to be forced into adapting to the adverse environment and this increases the allostatic load to a critical level. Avoiding such effects during the smolting stage could prove to be an important goal for salmon management.

\section{ACKNOWLEDGEMENTS}

We thank Anne Aasjord and the staff at ILAB for all their help during the study. We also thank the Vosso Hatchery and Vosso Restoration project for providing the fish.

\section{AUTHOR CONTRIBUTIONS}

L.O.E.E., V.A.B. and C.G. participated in the experimental design and all experiments. All authors participated in drafting the manuscript. L.O.E.E., J.N., V.T. and V.A.B. were involved in maze design and behavioural studies. L.O.E.E. C.G., T.O.N., S.O.H., S.O.S. and V.T. carried out sampling. H.-C.T. conducted water chemistry analysis. L.O.E.E., T.O.N. and V.T. participated in gene expression analyses. G.F. and M.G. analysed cortisol and S.O.H. analysed glucose. L.O.E.E., C.G. and V.A.B. conceived the study and drafted the final manuscript. All authors participated in editing the final manuscript.

\section{COMPETING INTERESTS}

No competing interests declared.

\section{FUNDING}

This study was supported by the Norwegian Research Council grant number 190469 (L.O.E.E., V.A.B. and S.O.S.), USDA grant PEN04296 (V.A.B.), and by the European Community's Seventh Framework Programme (FP7/2010-2014) under grant agreement no. 265957 - COPEWELL (L.O.E.E., G.F. and M.G.).

\section{REFERENCES}

Banasr, M. and Duman, R. S. (2007). Regulation of neurogenesis and gliogenesis by stress and antidepressant treatment. CNS Neurol. Disord. Drug Targets 6, 311-320.

Barton, B. A. (2002). Stress in fishes: a diversity of responses with particular reference to changes in circulating corticosteroids. Integr. Comp. Biol. 42, 517-525.

Barton, B. A. and Iwama, G. K. (1991). Physiological changes in fish from stress in aquaculture with emphasis on the response and effects of corticosteriods. Annu. Rev. Fish Dis. 1, 3-26.

Begg, K. and Pankhurst, N. W. (2004). Endocrine and metabolic responses to stress in a laboratory population of the tropical damselfish Acanthochromis polyacanthus. $J$ Fish Biol. 64, 133-145.

Biro, P. A., Post, J. R. and Booth, D. J. (2007). Mechanisms for climate-induced mortality of fish populations in whole-lake experiments. Proc. Natl. Acad. Sci. USA 104, 9715-9719.

Brady, L. D. and Griffiths, R. A. (1995). Effects of $\mathrm{pH}$ and aluminum on the growth and feeding-behavior of smooth and palmate newt larvae. Ecotoxicology 4, 299-306.

Braithwaite, V. A. and de Perera, T. B. (2006). Short-range orientation in fish: How fish map space. Mar. Freshw. Behav. Physiol. 39, 37-47.

Camargo, M. M. P., Fernandes, M. N. and Martinez, C. B. R. (2009). How aluminium exposure promotes osmoregulatory disturbances in the neotropical freshwater fish Prochilus lineatus. Aquat. Toxicol. 94, 40-46.

Chomczynski, P. (1993). A reagent for the single-step simultaneous isolation of RNA DNA and proteins from cell and tissue samples. Biotechniques 15, 532-534, 536537

Conrad, C. (2010). A critical review of chronic stress effects on spatial learning and memory. Prog. Neuropsychopharmacol. Biol. Psychiatry 34, 742-755.

Dittman, A. H., Quinn, T. P. and Nevitt, G. A. (1996). Timing of imprinting to natural and artificial odors by coho salmon, Oncorhynchus kisutch. Can. J. Fish. Aquat. Sci. 53, 434-442.

Dudgeon, D., Arthington, A. H., Gessner, M. O., Kawabata, Z., Knowler, D. J., Lévêque, C., Naiman, R. J., Prieur-Richard, A. H., Soto, D., Stiassny, M. L. and Sullivan, C. A. (2006). Freshwater biodiversity: importance, threats, status and conservation challenges. Biol. Rev. Camb. Philos. Soc. 81, 163-182.

Dufton, C., Marcora, E., Chae, J. H., McCullough, J., Eby, J., Hausburg, M., Stein G. H., Khoo, S., Cobb, M. H. and Lee, J. E. (2005). Context-dependent regulation of NeuroD activity and protein accumulation. Mol. Cell. Neurosci. 28, 727-736.

Ebbesson, L. O. E. and Braithwaite, V. A. (2012). Environmental effects on fish neural plasticity and cognition. J. Fish Biol. 81, 2151-2174.

Ebbesson, L. O. E., Deviche, P. and Ebbesson, S. O. E. (1996a). Distribution and changes in mu- and kappa-opiate receptors during the midlife neurodevelopmental period of Coho salmon, Oncorhynchus kisutch. J. Comp. Neurol. 366, 448-464.

Ebbesson, S. O. E., Smith, J., Co, C. and Ebbesson, L. O. E. (1996b). Transient alterations in neurotransmitter levels during a critical period of neural development in coho salmon (Oncorhyncus kisutch). Brain Res. 742, 339-342.

Ebbesson, L. O. E., Ekström, P., Ebbesson, S. O. E., Stefansson, S. O. and Holmqvist, B. (2003). Neural circuits and their structural and chemical reorganization in the light-brain-pituitary axis during parr-smolt transformation in salmon. Aquaculture 222, 59-70.

Ebbesson, L. O. E., Ebbesson, S. O. E., Nilsen, T. O., Stefansson, S. O. and Holmqvist, B. (2007). Exposure to continuous light disrupts retinal innervation of the preoptic nucleus during parr-smolt transformation in Atlantic salmon. Aquaculture 273, 345-349.

Ebbesson, L. O. E., Nilsen, T. O., Helvik, J. V., Tronci, V. and Stefansson, S. O. (2011). Corticotropin-releasing factor neurogenesis during midlife development in salmon: genetic, environmental and thyroid hormone regulation. J. Neuroendocrinol. 23, 733-741.

Eliason, E. J., Kiessling, A., Karlsson, A., Djordjevic, B. and Farrell, A. P. (2007) Validation of the hepatic portal vein cannulation technique using Atlantic salmon Salmo salar L.). J. Fish Biol. 71, 290-297.

Folgueira, M., Anadón, R. and Yáñez, J. (2004). An experimental study of the connections of the telencephalon in the rainbow trout (Oncorhynchus mykiss). Olfactory bulb and ventral area. J. Comp. Neurol. 480, 180-203.

Gensemer, R. W. and Playle, R. C. (1999). The bioavailability and toxicity of aluminum in aquatic environments. Crit. Rev. Environ. Sci. Technol. 29, 315-450.

Gorissen, M., Bernier, N. J., Manuel, R., de Gelder, S., Metz, J. R., Huising, M. O. and Flik, G. (2012). Recombinant human leptin attenuates stress axis activity in common carp (Cyprinus carpio L.). Gen. Comp. Endocrinol. 178, 75-81.

Gregory, T. R. and Wood, C. M. (1999). The effects of chronic plasma cortiso elevation on the feeding behaviour, growth, competitive ability, and swimming performance of juvenile rainbow trout. Physiol. Biochem. Zool. 72, 286-295.

Guerold, F., Boudot, J. P., Jacquemin, G., Vein, D., Merlet, D. and Rouiller, J. (2000). Macroinvertebrate community loss as a result of headwater stream acidification in the Vosges Mountains (N-E France). Biodivers. Conserv. 9, 767-783.

Hansen, L. P., Jonsson, N. and Jonsson, B. (1993). Oceanic migration in homing Atlantic salmon. Anim. Behav. 45, 927-941.

Harrenstien, L. A., Tornquist, S. J., Miller-Morgan, T. J., Fodness, B. G. and Clifford, K. E. (2005). Evaluation of a point-of-care blood analyzer and determination of reference ranges for blood parameters in rockfish. J. Am. Vet. Med. Assoc. 226, 255-265.

Hasler, A. D., Scholz, A. T. and Goy, R. W. (1983). Olfactory imprinting and homing in salmon. In Zoophysiology Vol. 14. New York, NY: Springer-Verlag.

Horne, M. T. and Dunson, W. A. (1995). The interactive effects of low pH, toxic metals, and DOC on a simulated temporary pond community. Environ. Pollut. $\mathbf{8 9}$ $155-161$

Kiefer, J. C., Jarman, A. and Johnson, J. (2005). Pro-neural factors and neurogenesis. Dev. Dyn. 234, 808-813.

Kolb, B., Gibb, R. and Robinson, T. (2003). Brain plasticity and behavior. Curr. Dir. Psychol. Sci. 12, 1-5.

Korte, S. M., Olivier, B. and Koolhaas, J. M. (2007). A new animal welfare concept based on allostasis. Physiol. Behav. 92, 422-428.

Korte, S. M., Prins, J., Vinkers, C. H. and Olivier, B. (2009). On the origin of allostasis and stress-induced pathology in farm animals: celebrating Darwin's legacy. Vet. J. 182, 378-383.

Korzh, V., Sleptsova, I., Liao, J., He, J. and Gong, Z. (1998). Expression of zebrafish bHLH genes $n g n 1$ and $n r d$ defines distinct stages of neural differentiation. Dev. Dyn. 213, 92-104.

Kroglund, F. and Finstad, B. (2003). Low concentrations of inorganic monomeric aluminum impair physiological status and marine survival of Atlantic salmon. Aquaculture 222, 119-133.

Kroglund, F., Finstad, B., Stefansson, S. O., Nilsen, T. O., Kristensen, T., Rosseland, B. O., Teien, H.-C. and Salbu, B. (2007). Exposure to moderate acid water and aluminum reduces Atlantic salmon post-smolt survival. Aquaculture $\mathbf{2 7 3}$ 360-373.

Kroglund, F., Rosseland, B. O., Teien, H.-C., Salbu, B., Kristensen, T. and Finstad, B. (2008). Water quality limits for Atlantic salmon (Salmo salar L.) exposed to short term reductions in $\mathrm{pH}$ and increased aluminum simulating episodes. Hydrol. Earth Syst. Sci. 12, 491-507.

Kroglund, F., Finstad, B., Pettersen, K., Teien, H.-C., Salbu, B., Rosseland, B. O. Nilsen, T. O., Stefansson, S. O., Ebbesson, L. O. E., Nilsen, R. et al. (2012) Recovery of Atlantic salmon smolts following aluminum exposure defined by changes in blood physiology and seawater tolerance. Aquaculture 362-363, 232-240.

Lema, S. C., Hodges, M. J., Marchetti, M. P. and Nevitt, G. A. (2005). Proliferation zones in the salmon telencephalon and evidence for environmental influence on proliferation rate. Comp. Biochem. Physiol. 141A, 327-335.

Liao, J., He, J., Yan, T., Korzh, V. and Gong, Z. (1999). A class of neuroD-related basic helix-loop-helix transcription factors expressed in developing central nervous system in zebrafish. DNA Cell Biol. 18, 333-344.

Liebich, T., McCormick, S. D., Kircheis, D., Johnson, K., Regal, R. and Hrabik, T. (2011). Water chemistry and its effects on the physiology and survival of Atlantic salmon Salmo salar smolts. J. Fish Biol. 79, 502-519.

Lovett, G. M., Tear, T. H., Evers, D. C., Findlay, S. E. G., Cosby, B. J., Dunscomb, J. K., Driscoll, C. T. and Weathers, K. C. (2009). Effects of air pollution on ecosystems and biological diversity in the eastern United States. Ann. N. Y. Acad. Sci. 1162, 99-135.

McCormick, S. D. (1993). Methods for nonlethal gill biopsy and measurement of $\mathrm{Na}^{+}$ $\mathrm{K}^{+}$-ATPase activity. Can. J. Fish. Aquat. Sci. 50, 656-658.

McCormick, S. D., Hansen, L. P., Quinn, T. P. and Saunders, R. L. (1998) Movement, migration, and smolting of Atlantic salmon (Salmo salar). Can. J. Fish Aquat. Sci. 55, 77-92.

McCormick, S. D., Keyes, A., Nislow, K. H. and Monette, M. Y. (2009). Impacts of episodic acidification on in-stream survival and physiological impairment of Atlantic salmon (Salmo salar) smolts. Can. J. Fish. Aquat. Sci. 66, 394-403.

Monette, M. Y. and McCormick, S. D. (2008). Impacts of short-term acid and aluminum exposure on Atlantic salmon (Salmo salar) physiology: a direct comparison of parr and smolts. Aquat. Toxicol. 86, 216-226.

Monette, M. Y., Björnsson, B. T. and McCormick, S. D. (2008). Effects of short-term acid and aluminum exposure on the parr-smolt transformation in Atlantic salmon 
(Salmo salar): disruption of seawater tolerance and endocrine status. Gen. Comp. Endocrinol. 158, 122-130.

Monette, M. Y., Yada, T., Matey, V. and McCormick, S. D. (2010). Physiological, molecular, and cellular mechanisms of impaired seawater tolerance following exposure of Atlantic salmon, Salmo salar, smolts to acid and aluminum. Aquat. Toxicol. 99, 17-32.

Mueller, T. and Wullimann, M. F. (2002). BrdU-, neuroD (nrd)- and Hu-studies reveal unusual non-ventricular neurogenesis in the postembryonic zebrafish forebrain. Mech. Dev. 117, 123-135.

Mueller, T. and Wullimann, M. F. (2003). Anatomy of neurogenesis in the early zebrafish brain. Brain Res. Dev. Brain Res. 140, 137-155.

Neff, K. J., Schwartz, J. S., Henry, T. B., Bruce Robinson, R., Moore, S. E. and Kulp, M. A. (2009). Physiological stress in native southern brook trout during episodic stream acidification in the Great Smoky Mountains National Park. Arch Environ. Contam. Toxicol. 57, 366-376.

Nilsen, T. O., Ebbesson, L. O. E., Kverneland, O. G., Kroglund, F., Finstad, B. and Stefansson, S. O. (2010). Effects of acidic water and aluminum exposure on gill $\mathrm{Na}^{+}, \mathrm{K}^{+}$-ATPase alpha-subunit isoforms, enzyme activity, physiology and return rates in Atlantic salmon (Salmo salar L.). Aquat. Toxicol. 97, 250-259.

Odling-Smee, L. C., Boughman, J. W. and Braithwaite, V. A. (2008). Sympatric species of threespine stickleback differ in their performance in a spatial learning task. Behav. Ecol. Sociobiol. 62, 1935-1945.

Ottoni, E. B. (2000). EthoLog 2.2: a tool for the transcription and timing of behavior observation sessions. Behav. Res. Methods Instrum. Comput. 32, 446-449.

Parrish, D. L., Behnke, R. J., Gephard, S. R., McCormick, S. D. and Reeves, G. H (1998). Why aren't there more Atlantic salmon (Salmo salar)? Can. J. Fish. Aquat. Sci. 55, 281-287.

Pfaffl, M. W. (2004). Quantification strategies in real-time PCR. In A-Z of Quantitative $P C R$ (ed. S. A. Bustin), pp. 1-23. San Diego, CA: International University Line.

Poléo, A. B., Østbye, K., Øxnevad, S. A., Andersen, R. A., Heibo, E. and Vøllestad, L. A. (1997). Toxicity of acid aluminium-rich water to seven freshwater fish species: a comparative laboratory study. Environ. Pollut. 96, 129-139.

Schindler, D. W. (1988). Effects of acid rain on freshwater ecosystems. Science 239, 149-157.

Shettleworth, S. J. (2010). Cognition, Evolution and Behavior, 2nd edn. Oxford: Oxford University Press.
Smith, P. K., Krohn, R. I., Hermanson, G. T., Mallia, A. K., Gartner, F. H., Provenzano, M. D., Fujimoto, E. K., Goeke, N. M., Olson, B. J. and Klenk, D. C. (1985). Measurement of protein using bicinchoninic acid. Anal. Biochem. 150, 76-85.

Sørensen, C., Øverli, Ø., Summers, C. H. and Nilsson, G. E. (2007). Social regulation of neurogenesis in teleosts. Brain Behav. Evol. 70, 239-246.

Sørensen, C., Bohlin, L. C., Øverli, Ø. and Nilsson, G. E. (2011). Cortisol reduces cell proliferation in the telencephalon of rainbow trout (Oncorhynchus mykiss). Physiol. Behav. 102, 518-523.

Sovrano, V. A., Bisazza, A. and Vallortigara, G. (2002). Modularity and spatial reorientation in a simple mind: encoding of geometric and nongeometric properties of a spatial environment by fish. Cognition 85, B51-B59.

Stefansson, S. O., Björnsson, B. T., Ebbesson, L. O. E. and McCormick, S. D. (2008). Smoltification. In Fish Larval Physiology (ed. R. N. Finn and B. G. Kapoor), pp. 639-681. Enfield, NH: Science Publishers.

Teien, H. C., Salbu, B., Kroglund, F. and Rosseland, B. O. (2004). Transformation of positively charged aluminium-species in unstable mixing zones following liming. Sci. Total Environ. 330, 217-232.

Teien, H. C., Andrén, C., Kroglund, F. and Salbu, B. (2005). Changes in gill reactivity of aluminium species following liming of acid and aluminium-rich humic water. Proceedings of the International Association of Theoretical and Applied Limnology, Vol. 29 (ed. J. Jones), pp. 837-840. Stuttgart: Schweizerbart Science Publishers.

Teien, H.-C., Kroglund, F., Salbu, B. and Rosseland, B. O. (2006). Gill reactivity of aluminium-species following liming. Sci. Total Environ. 358, 206-220.

von Krogh, K., Sørensen, C., Nilsson, G. E. and Øverli, Ø. (2010). Forebrain cell proliferation, behavior, and physiology of zebrafish, Danio rerio, kept in enriched or barren environments. Physiol. Behav. 101, 32-39.

Wendelaar Bonga, S. E. (1997). The stress response in fish. Physiol. Rev. 77, 591625.

Yamamoto, Y., Hino, H. and Ueda, H. (2010). Olfactory imprinting of amino acids in lacustrine sockeye salmon. PLOS ONE 5, e8633.

Zupanc, G. K. H. (2008). Adult neurogenesis and neuronal regeneration in the brain of teleost fish. J. Physiol. Paris 102, 357-373.

$\varnothing v e r l i, \varnothing$., Sørensen, C. and Nilsson, G. E. (2006). Behavioral indicators of stresscoping style in rainbow trout: Do males and females react differently to novelty? Physiol. Behav. 87, 506-512. 